Article

\title{
Cold War Transgressions: Christian Realism, Conservative Socialism, and the Longer 1960s
}

\author{
Mark Thomas Edwards \\ Department of History, Spring Arbor University, 723 Woodlawn Ave., Jackson, MI 49203, USA; \\ E-Mail: mark.edwards@arbor.edu; Tel.: +1-517-962-4743
}

Academic Editor: Darren Dochuk

Received: 13 January 2015 / Accepted: 13 March 2015 / Published: 20 March 2015

\begin{abstract}
This essay examines the convergence of the Protestant left and traditionalist right during the 1950s. Reinhold Niebuhr and the World Council of Churches challenged Cold War liberalism from within. As they did, they anticipated and even applauded the anti-liberalism of early Cold War conservatives. While exploring intellectual precursors of the New Left, this essay forefronts one forgotten byproduct of the political realignments following World War II: The transgressive politics of "conservative socialism." Furthermore, this work contributes to growing awareness of ecumenical Christian impact within American life.
\end{abstract}

Keywords: protestantism; liberal protestantism; conservativism; liberalism; cold war; christian realism; ecumenism; reinhold niebuhr; world council of churches; new left

\section{Introduction}

This essay remembers two interrelated forerunners of the 1960s New Left. The young, white "radical liberals" of that era distanced themselves from the Old Left by rejecting the organized working class as a force for distributive social justice [1,2]. They instead sought to reconcile values of personal authenticity and inclusive solidarity, as reflected in their premier statement of principles, the "Port Huron Statement" (PHS, 1962). The PHS was produced by Tom Hayden and the Students for a Democratic Society (SDS). It outlined several "hidden" problems, including Jim Crow, racialized urban poverty, the military-industrial complex, and the increasing bureaucratization of American life. Hayden and the SDS castigated citizens for their submission to the totalitarian-like controls of a supposedly liberal egalitarian political order. They summoned Americans to realize a "democracy of 
equal participation" characterized by radical decentralization of political, economic, and cultural power. Many present-day communitarian movements on the left and right continue to echo the SDS manifesto [3].

The politically heterodox nature of the PHS is revealed when considering its intellectual origins. Though it is impossible to know all of a group document's sources, a few of the PHS's forgotten ones can help us better understand the political revolutions of the post-World War II years. The SDS catchphrase, "participatory democracy", was the brainchild of Hayden's University of Michigan professor, Arnold Kauffman. The overall analysis of the PHS flowed from another New Left mentor, Columbia sociologist C. Wright Mills. However, what happens when we recall Hayden's "other" influences at the time he crafted the PHS? A look at his reading lists uncovers some more familiar and forgotten names, including John Dewey, Reinhold Niebuhr, and Robert Nisbet ([2], pp. 93-95).

That Hayden had read Dewey and Niebuhr should not be too surprising, given their iconic status as members of the Old Left. Hayden read Niebuhr mainly to prove Niebuhr's Christian Realist arguments against achieving heaven on earth wrong ([2], pp. 122, 135). The Christian Realist movement had arisen in America during the 1920s and 1930s [4-6]. It was one response to the inability of evangelical Protestants to form a more spiritual and ethical urban-industrial capitalist civilization. Synthesizing theological shifts abroad and Marxist critiques at home, Christian Realists called for a renewed separation of the "Church" from the "World". American Realists placed themselves at the center of ongoing trans-Atlantic and transnational efforts to build an ecumenical "World Christian Community". The geopolitics of World War II and the Cold War moderated the Realists' initially radical class interests. However, they never became the spiritual anchors of corporate liberal anticommunism. Such a false portrait stems from historians' continuing over-identification of Christian Realism with Niebuhr.

While Hayden's critical attraction to Niebuhr was understandable, his decision to engage Nisbet might be more unexpected: Nisbet was a leader of the so-called "new conservativism". As historian George Nash outlined some years ago, post-World War II conservativism represented a "fusion" of three intellectual strains: traditionalism, libertarianism, and globalist anticommunism [7]. Those factions have always been uneasily intermingled, such as in the life and career of William F. Buckley, Jr., and The National Review, for instance. However, it is also evident that libertarians and anticommunist (now anti-terrorist) globalists have long dominated postwar conservativism - eventually renamed the New Right. To be sure, evangelical Protestant defenders of "family values" have benefitted immensely from recent historical attention to conservativism's origins [8-10]. Though not receiving the close coverage of their evangelical counterparts, Roman Catholic conservatives have also not been neglected [11]. Yet where to situate Nisbet and the other original voices of traditionalist conservativism? Hayden's source material for the PHS suggests a new location.

This essay seeks to find the "Hayden" in Niebuhr and Nisbet - to examine intellectual precursors of New Left communitarianism among the early Cold War left and right. It adds to the growing literature on the "long 1960s" [12]. Historians are just beginning to narrate the lasting impression of the radical movements of that decade. In considering the intellectual antecedents of New Left participatory democracy, this essay recovers a longer twentieth-century lineage of protest against what William James once termed "overwhelming bigness" [13]. Several scholars have already documented connections between the New Left and the trans-Atlantic Progressivism of James, Jane Addams, and her 
protégé John Dewey [14-16]. There were other standard bearers of democratic Progressive concerns, however - namely Niebuhr's old Protestant left and Nisbet's new traditionalist right.

That is not to suggest that Hayden and the New Left were deeply or directly influenced by those movements; nor is it to imply that they were the only two coalitions advocating for more local community control (Roman Catholics on the left and right did so throughout the twentieth century). Rather, the two groups highlight an unexpected convergence of cultural political complaint during the 1950s. Section 2 of this essay explores the formation of Christian Realism within the old ecumenical Protestant left and how it diverged in important ways from early Cold War liberalism. Section 3 resurrects traditionalist conservatives and examines their affinities to and for the Protestant left. Finally, this essay reimagines the New Left and comments on the historiographical problems pertaining to what might be termed the "liberal-conservative binary".

In advancing participatory democratic alternatives to the Cold War liberal state and society-before the New Left-Christian Realists and traditionalist conservatives transgressed familiar categories of left and right. The admittedly contested "Cold War liberal consensus" of the 1950s and 1960s, as expressed in Arthur Schlesinger, Jr.'s, The Vital Center (1949) and by the Americans for Democratic Action (ADA), had tried to fuse military-capitalist expansion with social security programs, minority civil rights, and Global Southern development into one transnational anticommunist modernization project [17]. Christian Realists challenged Schlesinger's new nation builders while remaining professing liberals. Traditionalists damned the consensus as campaigners for the new conservativism. What is significant here is how insider (Christian Realist) and outsider (traditionalist) critiques of Cold War modernism coincided, particularly in their common rejection of "mass" American society. Both groups showed how the postwar revival of interest in Edmund Burke, the widely regarded "father of modern conservativism", was orchestrated by confessing liberals as well as conservatives [18]. Together, Christian Realists, traditionalists, and even the New Left looked to Burke for support for their varied communitarian sensibilities. In doing so, they exposed the dangers of reading backwards the current liberal-conservative binary - itself a result of the Cold War culture wars [19] — to make sense of twentieth-century American politics.

In contributing to efforts to denaturalize the American right and left, this essay adds to the ongoing rehabilitation of interest in liberal and ecumenical Christianity. A number of recent and forthcoming studies - led by David Hollinger and his students - are pioneering new ways of looking at the old idea of an American "Protestant Establishment" [20-29]. Some of these works reinforce the familiar story of "mainline decline" and "evangelical ascendancy". Others document the deep and lasting impact on Americans of ecumenical Christian movements and liberal Protestant culture more generally. This essay shows how liberal and ecumenical church leaders dared their nation to live up to its democratic professions. It does not lionize the Christian Realists nor minimize their limited perspectives on race, gender, and sex equality. It does show how earnestly, faithfully, and creatively some Protestants sought to reapply trans-Atlantic Progressive ideals to changing national and world situations. Christian Realists constituted an original moral minority_rejecting "corporate evangelicalism" [30] and calling upon Americans to conserve human dignity and potential through the decentralization of corporate capitalist political economy. 


\section{Christian Realism: The Old Ecumenical Protestant Left Confronts Cold War Liberalism}

Historians have had a hard time breaking the habit of reading Christian Realism narrowly through Niebuhr's writings [31-34]. Of course, that is not to dismiss the excellent work of the "Niebuhr revival” led by Richard Fox, John Patrick Diggins, Martin Hallowell, Daniel Rice, Healan Gaston, Andrew Bacevich, William Inboden, and so many others. The point is rather that Christian Realism was so much more than a "great man" project. The earliest accounts of the movement had situated Niebuhr alongside his many colleagues, collaborators, and critics [35]. More recently, Heather Warren and this author have attempted to restore other key voices of the old Protestant left community [4,5]. In particular, Warren and I see Christian Realism as a partnership sponsored by the Theological Discussion Group, a thirty-person project that began meeting bi-annually at Yale Divinity School in 1933. The Group boasted several of the biggest up-and-coming names in liberal Christianity, including Niebuhr, his brother H. Richard, and Paul Tillich. Its organizers, however, were Henry Pitney Van Dusen (professor and eventual president of Niebuhr's Union Theological Seminary in New York), Francis Pickens Miller (chairman of the World's Student Christian Federation (WSCF)), John Coleman Bennett (a New York Christian socialist and Niebuhr disciple), Samuel McCrea Cavert (Executive Secretary of the Federal Council of Churches (FCC)), and Walter Marshall Horton (author of Realistic Theology in 1934). It was Bennett, Horton, and Cavert who first adopted the label "realism" for their Group [36-39]. In fact, Van Dusen and associates considered omitting Niebuhr from the final roster. They were upset with his argument in Moral Man and Immoral Society (1932) that proletarian dictatorship was a self-fulfilling prophecy [40].

To be sure, most Theological Discussion Group founders would have considered themselves affiliates if not card-carrying members with Niebuhr in the old Protestant left. Like the New York-based Old Left it intersected with, the old Protestant left had its origins in trans-Atlantic Progressivism. The political theologians of that era had accommodated the strong-state revolution advocated by Teddy Roosevelt and the New Republic. Federal regulation, for them, was nevertheless a means toward the end of the "real" participatory democracy envisioned by reformers such as Jane Addams and John Dewey [41-43]. During the 1920s, younger liberal Protestants followed their mentors in searching for a genuine religious radicalism shorn of early social Christianity's enforcement of Victorian cultural norms. The old Protestant left was always diverse, ranging from Communist Party leaders (Harry Ward) and Socialist Party supporters (the Niebuhrs and Bennett) to New Deal Democrats (Miller) and even liberal Republicans (Van Dusen). It did tend to follow British political and social thought fairly closely, though, especially that of Archbishop William Temple and the Labour Party. Miller and the Niebuhrs added a greater sense of political realism through their attention to imbalances of class and race power.

Christian Realism was both a part of and yet separate from classical expressions of political realism (I use "Realism" as opposed to "realism" in several places to refer specifically to Christian Realism). Like other realists, Christian Realists believed that social order and justice was best realized through the balancing of opposing forces. At first, that meant aiding the formation of an independent farm-labor movement tough enough to check techno-corporate business interests. Later, Christian Realists followed the realist mainstream in advocating for a preponderance of American power against 
totalitarian regimes. At the same time, Christian Realists distanced themselves from religiously unaffiliated forms of realism by their efforts to expand liberal Protestant influence.

In other words, the watershed issue for the younger old Protestant left was not communism but rather the place of the church in social and geopolitical struggles. In opposition to Niebuhr-who, Miller complained, had "no theory of the Church" [44]—Van Dusen's Realists would pursue personal and collective fulfillment in advancing the cause of global Christian ecumenism. The world ecumenical movement was the brainchild of foreign missions cooperation during the nineteenth century. Efforts to build a "World Christian Community" during the 1920s and 1930s were led by several interdependent networks, including the Life and Work conference, the International Missionary Council (IMC), and Miller's WSCF. The idea for a Protestant "Vatican" was proposed by Miller in tandem with two other churchmen: IMC leader J. H. Oldham and the general secretary of the WSCF, Willem A. Visser ' $t$ Hooft [45]. Their dream was realized when the World Council of Churches (WCC) was formally launched at Amsterdam in $1948[4,5,25,26]$.

The WCC demonstrated the broad reaches of the "Christian Realism" label, as Oldham and British ecumenical founders also used it in their writings ([45], p. 393). The WCC's own "realism" was evident in founders' vision of a transnational, counter-totalitarian "Christian Internationale", or what Miller termed a "higher form of collectivism". As Miller described in 1933, the paramount problem of the twentieth century was the arrival of the "totalitarian state". He was among a growing number of Protestants convinced that the "Church Universal" had to do what no single nation-state could. "Since the only force strong enough to check one form of collectivism is a higher form of collectivism", Miller explained, "the absolutism of the nation can only be limited by a super-national society" [46,47]. Miller's projected global Christian coalition would disarm the pure power politics heralded in Niebuhr's Moral Man by meeting lower with higher spiritual-ethical strength. His reflections are significant for highlighting that Niebuhr was not the only liberal and ecumenical Protestant to develop and promote politically realist sensibilities. They are also important for countering the longstanding notion that liberal and ecumenical Protestants are necessarily cultural accommodationists.

The ecumenical conviction that "the Church" should stand together against "the World" was most reflected in their careful navigation of superpower bipolarity. Realist and the WCC had championed Christian Anglo-American unity against Fascism during World War II. Yet they refused to take sides in the mounting conflict between the United States and the Soviet Union [26,48-50]. "The Iron Curtain did not and would not exist" for the ecumenical community, Visser 't Hooft concluded ([48], pp. 55, 64). He, Cavert, and the WCC wanted most of all to "show the world that we are absolutely independent from all governmental influence" [51]. It is true that American Realists like Niebuhr and Bennett, through their journal Christianity and Crisis, came to speak mainly to and for the Cold War liberal consensus during the 1950s [52]. Christian Realism could not be so simply contained, however. WCC study material, which Realists like Van Dusen and Miller also helped shape, reveals that the Anglo-American ecumenical community was in search of democratic socialist alternatives to anti-communist liberalism. Even Niebuhr, the most outspoken and influential Christian American anti-communist, still looked longingly to the Labour Party for a "third way" between market and command political economies [53,54].

With Christian Realists often at the helm, the old ecumenical Protestant left went on to challenge the Cold War liberal consensus from within. The WCC's own self-described "third way" or "third 
force" found expression in their Cold War demands for a Responsible Society [55]. The Responsible Society was the name of the WCC's social ideal unveiled at its inaugural meeting. After considering other slogans, such as "free society" and "humane society", Oldham and Visser "t Hooft, in conversation with Van Dusen and Indian church leaders, returned to discourses on "social responsibility" that had become operative during the trans-Atlantic Progressive era [56]. According to the "Disorder of Society" committee, co-chaired by Oldham and Niebuhr, "a responsible society is one where freedom is the freedom of men who acknowledge responsibility to justice and public order, and where those who hold political authority or economic power are responsible for its exercise to God and the people whose welfare is affected by it" [57]. Responsible Society advocates assumed that advances in economic justice and civil rights were only possible on a broadly Christian foundation. A healthy dose of theocratic consciousness raising was necessary to reinvigorate Western democratic principles.

Oldham saw the Responsible Society as a way out of a planetary "crisis of culture" ([55], p. 125). Ecumenical literature coming out of Oxford and Amsterdam echoed and advanced protests against what many would call the "mass society" [58]. Although usually associated with 1950s thought, culture critics across the ideological spectrum - from Jane Addams and Lewis Mumford to Jose Ortega y Gasset and Christopher Dawson - had been complaining for decades that urban-industrialism had set in motion the destruction of local associations like the family, the neighborhood, and the small town. That degradation of community bonds had left behind an undifferentiated jumble of humanity awaiting manipulation by some sort of totalitarian leadership [59]. As Niebuhr summarized mass society theory, "the total effect of the rise of modern industry has been the destruction of community on the national level and the extension of conflict on the international level" [60]. Niebuhr and ecumenical associates targeted techno-corporate capitalism, or "technics" ([60], p. 16) as the mass society's prime mover. Meanwhile, the totalitarian "revolt against both the Christian and the secular forms of the liberal society" had exacerbated rather than resolved the felt need to reintegrate all that had been atomized by open door commercialism ([60], p. 20).

Similarly, Oldham noted that the various "disintegrating influences" Westerners now specialized in were beginning to overtake Asia, Africa, and elsewhere ([55], p. 125). In light of failed Nazi and Soviet solutions, the WCC defended the religious, political, and economic liberties that they believed to be the first fruits of Western Christian civilization. However, Oldham's men hoped to combine classical liberal rights with a more elusive emphasis on participatory democratic justice ([55], p. 153).

The majority of solutions to the mass society proposed by atheist (Jean-Paul Sartre), Jewish (David Riesman), and Christian (Paul Tillich) public intellectuals during the 1950s arose from existentialist philosophy. They pitted the solitary, "inner-directed" person against their soul-less civilization [61]. Realists and other WCC writers preferred socialist, participatory democratic alternatives. According to the Niebuhr/Oldham report, the Responsible Society was intended to "preserve the possibility of a satisfying life for "little men in big societies"" [57]. Any realistic reform assessment, Oldham and commission writers maintained, had to come to terms with the broad desire to decentralize "vast concentrations of power" that had arisen within both capitalist and communist spheres of influence ([57], p. 190). Economic and political opportunity, as the precondition of responsible relations, had to be restored, defended, and secured seemingly everywhere.

The Niebuhr/Oldham report made ecumenical communitarianism even more explicit. "For a society to be responsible under modern conditions", it explained, "it is required that the people have freedom 
to control, to criticise and to change their governments, that power be made responsible by law and tradition, and be distributed as widely as possible through the whole community. It is required that economic justice and provision of equality of opportunity be established for all the members of society" [57]. To be sure, the ecumenical community rarely practiced Christian communitarian to the extent of the Catholic Worker movement [62]. Nevertheless the ecumenical vision of society did favor downsizing to a degree underappreciated by historians of the old ecumenical Protestant left. As the Niebuhr/Oldham report continued,

Centres of initiative in economic life must be so encouraged as to avoid placing too great a burden upon centralized judgment and decision. To achieve religious, cultural, economic, social and other ends it is of vital importance that society should have a rich variety of smaller forms of community, in local government, within industrial organisations, including trade unions, through the development of public corporations and through voluntary associations. By such means it is possible to prevent an undue centralization of power in modern technically organized communities, and thus escape the perils of tyranny while avoiding the dangers of anarchy [57].

Realists and their ecumenical associates never sold out to techno-corporate visions of American greatness. Instead, they coopted Cold War liberal rhetoric while prefiguring New Left participatory democracy.

A follow-up study on the Responsible Society made that connection even more explicit. Miller served as chairman for a committee that included initially Niebuhr and Bennett (Niebuhr quit midway through). Several notables also became involved, including Senators H. Paul Douglas and Frank Graham, as well as anti-communist labor spokesman Walter Reuther. The group's democratic Progressive credentials were impeccable. Members circulated the question to fellow churchpersons and politicians, "how can Americans become as "obligation" conscious as they are "rights" conscious" [63]? Miller and friends concluded that a Responsible Society required increasing personal "participation" in public life while checking the "trend toward bigness" [64]. Governments had to create better social conditions for the exercise of "responsible freedom" by their citizens [65].

Realists also debated responsible economic restructuring with Ivy League economists and social scientists. The occasion was the Rockefeller family-funded "Ethics and Economic Life" studies conducted between 1949 and 1955 for the WCC and the FCC - the latter was subsumed by the National Council of Churches (NCC) in 1950. Most writers admitted the profit motive as the irreplaceable key to capitalism's amazing material productivity [66]. All the same, Bennett and others doubted that being "tied to a dynamic economy" was the condition most conducive to promoting personal and collective responsibility [67]. They were never consumed by economic "growth" as the solution to capitalist inequities in the way that some Cold War liberals and their libertarian conservative critics would be [68].

Among the celebrity economic theories debated among series authors, economist John Kenneth Galbraith's notion of "countervailing power" most pervaded their writings-largely because it summarized Niebuhr's Moral Man argument that oppressed groups first had to organize if they were to overcome systemic inequalities [69]. Participants agreed that further centralization of the economy would be deleterious to the nurture of healthy personalities. Despite differences over means, economist 
Kenneth Boulding and Niebuhr united in support of a "polylithic society" featuring numerous centers of power [70]. A genuine pluralistic civilization could more ably preserve what the latter called the "hard shells of community" [71].

The Realist and ecumenical communities expressed more positive appreciation for capitalism and the "limited state" during the 1950s [72]. That did not alter their pleas to disperse economic decision-making as widely as possible [73]. "The idea of a mixed economy with large measures of social control and social ownership", economist Howard R. Bowen understood, "seems more acceptable to Protestant thinkers than to businessmen" [74]. Bowen counseled against placing "utopian demands" upon the business world ([74], p. 140). Nevertheless, he proposed a number of schemes to make the WCC's "doctrine of broader participation" a reality for the trans-Atlantic working classes ([74], p. 177). Among those plans, "Industrial Councils"-self-governing committees of owners, managers, and worker representatives, which were already popular among Catholic and CIO labor organizers - won praise from veteran public theologians as one approximation of a cooperative society ([74], pp. 168-76; [75]). It was believed that more considerable efforts were required to bring workers into the culture of reciprocity that marked Responsible Society discourse.

The demands made by the old ecumenical Protestant left to decentralize the techno-corporate commonwealth represented a challenge from within Cold War liberalism. Following World War II, Christian Realists and their WCC allies fought to hold together the trans-Atlantic social democracy networks of the Progressive era against a multitude of threats. Professing liberals, during the 1950s, were willing to sacrifice advances in economic and racial democracy out of zeal for "national security". At the same time, a self-described conservative movement fronted by William F. Buckley, Jr., and the National Review proposed to lay waste to the New Deal state while supercharging the military-industrial complex. The convergence of liberal-conservative efforts to preserve American freedoms through faith in what Buckley once called "the instrument of a totalitarian bureaucracy within our shores" was indeed curious [76]. It was matched only by a greater transgression: The unity of Christian Realist and traditionalist conservative concern for what the latter would call conservative socialism.

\section{Conservative Socialism: Situating the Cold War Traditionalists}

Remembrance of that counterintuitive connection should affect the way historians narrate the American left, right, and center. The new political histories of the New Right have uncovered much in terms of business and grassroots mobilization but often to the neglect of movement intellectuals [77-80]. Traditionalist conservatives have been the most marginalized of all. That is because they do not fit well into the contemporary liberal-conservative binary that historians continue to impose upon the past. To be sure, the traditionalist faction of the New Right today-dominated as it is by Catholic and evangelical voices - has accommodated much of the limited government/limitless military aims of the post-World War II conservative mainstream. Not so traditionalism's four earliest and most influential spokespersons: Peter Viereck, Russell Kirk, Richard Weaver, and Robert Nisbet. Viereck, who coined the title "new conservativism", was a poet and historian. Kirk became the most venerated and decorated traditionalist intellectual within the New Right. Weaver, an English professor at the University of Chicago, began public life as a member of the Socialist Party before converting to 
Southern Agrarianism. Finally, Nisbet emerged as one of the most influential sociologists of the postwar era before attaining to the Albert Schweitzer Chair at Columbia University.

Like Christian Realists, those writers found sources for criticizing Cold War politics and culture in the intellectual traditions of trans-Atlantic Progressivism, including the New Deal. They, too, looked forward with ecumenical Protestants to the restoration of "the humane scale" [81]. In so doing, they relativized the terms "liberal" and "conservative" by pointing to new and forgotten arrangements of political, economic, and cultural power that Viereck called conservative socialism.

The distance between traditionalist and libertarian conservativism - the majority conservativism today - could be seen early on by one of the new conservativism's first chroniclers, the Bancroft prize-winning historian Clinton Rossiter. Writing in the wake of Kirk's landmark synthesis, The Conservative Mind (1953), Rossiter proudly and subversively proclaimed America a "citadel of conservativism" [82]. "The essence of Conservativism", Rossiter maintained, "is the feeling for the possibilities and limits of natural, organic change" ([82], p. 29). The Conservative prized "ordered liberty", the "aristocratic spirit", "equity" over "equality", and the "diffusion of power" ([82], pp. 24, 33, 40-42, 47-52). Historians of late have challenged that self-portrait still painted by today's paleo-conservatives and some neoconservatives. From its inception, these historians maintain, Cold War conservativism has displayed reckless utopianism, populist incivility, and rebel zeal $[83,84]$. Rossiter actually anticipated their charge, arguing that America's normative "laissez-faire conservativism", typified by "rugged individualism" and "anti-intellectualism", was at best an inglorious bastard of the real thing ([82], pp. 133-35, 214-42). He hoped the "new conservativism" was poised to prevail over the manifold wrongs of America's sham-right. But why would Rossiter conclude that new conservatives "must go to school with Reinhold Niebuhr", an avowed realistic liberal ([82], p. 254)?

Rossiter mainly spoke for and to traditionalist conservatives who shared Christian Realists' distrust of centralized power-he specifically named Viereck, Kirk, Nisbet, and Weaver alongside Niebuhr ([82], pp. 210-11). In demanding a "new conservativism" in 1940, Viereck had hoped to bring together those still believing in absolute truth against totalitarian might-makes-right [85]. Viereck also juxtaposed "civilization" and "mass-man" in his 1949 manifesto, Conservativism Revisited [86]. As he explained, the much-touted "century of the common man" had culminated in the "ant-heap age" of the 1940s [86]. John Stuart Mill's utilitarian democratic sensibility now needed to be tempered by the aristocratic wisdom of Edmund Burke. An Anglo-American conservativism such as Burke's, Viereck explained, would act as "social and cultural cement, holding together what western man has built and by that very fact providing a base for orderly change and improvement" ([86], pp. 32, 123). As Viereck's comment suggests, most early Cold War traditionalists rejected liberal characterizations of Burke as a reactionary against democratic reform. That is not to say that a singular "American Burke" ever existed. However, historians have uncovered a long line of interpreters who echoed Viereck's portrait of a Burke as a cautious progressive [18].

Besides Burke, Viereck found an unlikely role model for new conservatives in German-Austrian foreign minister Prince Metternich (the hero of Viereck's earlier work on nineteenth-century German nationalism). Viereck made much of Metternich's self-characterization as a "conservative socialist" in arguing that new conservatives needed to embrace, of all things, New Deal liberalism ([86], pp. 97, 126). Viereck's self-titled "heterodox" conservativism did not for long endear him to the vital conservative 
center at the National Review [87]. It did, however, situate him within the mainstream of twentieth-century trans-Atlantic Progressive thought occupied earlier by the Realists and the WCC.

Viereck's shorthand for essential conservativism as "the political secularization of the doctrine of original sin" helps explain why Rossiter insisted that new conservatives needed to learn from Niebuhr ([86], p. 47). The Times Literary Su pplement had already lumped Viereck and Niebuhr together as the two most profound American writers of the postwar era ([86], p. 6). Viereck himself referenced Niebuhr as a kindred spirit alongside Rossiter and sociologist of American pluralism Will Herberg ([86], p. 139). In turn, Herberg uplifted both Viereck and Niebuhr as exemplars of "good, sound, responsible conservativism" in contrast to reckless McCarthyism [88]. A few years later, Herberg tried to sell Niebuhr as a "Burkean conservative" to National Review readers [89].

The point here is not to revive the tired charge that Niebuhr followed Herberg into neoconservativism - others have already exonerated him [90]. The very word "neoconservative" took hold among pundits and historians to preserve the liberal-conservative binary and thus obscure all the ways that Niebuhr and friends defied it. It is more important to recognize that right-left-center interest in Niebuhr's few writings on Burke have masked what the old ecumenical Protestant left as a whole shared with traditionalist conservatives. Both movements came to believe that a genuine conservativism respectful of Burke had to be built on a foundation of distributive justice - such as that found in trans-Atlantic Progressivism and the New Deal. "Those who speak today from the point of view of an enlightened conservativism", Bennett explained in 1956 (referencing Burke), "must presuppose the overcoming of the great inequalities which have humiliated and burdened most of humanity" [91]. Bennett's sentiment was transgressive of the liberal-conservative binary but not necessarily atypical, as even Schlesinger, Jr., and other Cold War liberals registered approval for Burke and traditionalist writings [92]. The postwar Burke revival, in other words, was made possible by the American left as well as right.

New conservative connections to earlier democratic Progressive reformers, Christian Realists, and even the New Left were most evident in their joint promotion of mass society criticism. Diagnosing the mid-century malaise of "empty atomic individuality”, Kirk's Conservative Mind suggested a culprit long familiar to Realists: liberalism [93]. Like most twentieth-century public intellectuals, Kirk rarely distinguished between liberalism's limited-government and strong-state variants. Coming of age in the early nineteenth century, Kirk charged, liberalism had involved "a transition from Christendom, aristocracy, and family-economy to an overwhelming utilitarian collectivism" [93]. Kirk doubted Burke would ever have conceded that a "consumption-society...is the end for which Providence has prepared man" ([93], p. 10). Like his contemporary religious liberal rivals, Kirk was convinced that "American mass society" prevented the formation of "authentic persons" [94].

Kirk's conservative genealogy echoed a more vicious, landmark assault on the "gods of mass and speed", Ideas Have Consequences (1948) by Richard Weaver [95]. Like interwar and postwar ecumenical Christian literature, Weaver targeted urbanization, industrialization, and unrestrained commercialism as the chief "spoiling" agents of the "enmassed" American public ([95], pp. 30-32, 51, 115). Weaver warned, "a spoiled people invite despotic rule" ([95], p. 91). Niebuhr concurred, lauding Weaver's anti-modernist masterpiece as "a profound diagnosis of the sickness of our culture". When Ideas became popular reading for the college student right during the 1960s, they would have 
encountered Niebuhr's endorsement (as well as one from Paul Tillich) on the 1962 edition dust jacket [96].

Another seminal tract for young radicals, Robert Nisbet's The Quest for Community, cut even more sharply across the liberal-conservative divide. Realists, the ecumenical community, and Kirk all lauded the Columbia sociologist for offering one of the most brilliant analyses of (invoking Alexis de Tocqueville) "democratic despotism" ([93], pp. 179, 420-27). In fact, Nisbet's book was one of the most popular mass society protests of the era (reissued as Community and Power during the 1960s to appeal especially to New Left readers). The chief characteristic of the twentieth century, Nisbet argued, was the search for fresh forms of large-scale associations to replace the dissolution of traditional, smaller ones. Like most new conservatives, Nisbet believed the "State" was poised to play the role of providence for mass men [97]. The State had bequeathed to its citizens "important humanitarian gains and personal liberties" ([97], p. 108). Yet it did so at the expense of commandeering the "supreme allegiance of men" ([97], p. 90). As an alternative to the "total community" ([97], p. 169), Nisbet advocated for a "new philosophy of laissez faire" rooted in the preservation and promotion of "autonomous groups" ([97], pp. 244-46). In framing his critique and cure, Nisbet borrowed frequently from Niebuhr. Niebuhr returned the favor in a brief letter exclaiming, "I think you have stated all our problems of community with great astuteness and fairness, and have pointed to the creative answers for which we must seek" [98]. Niebuhr's endorsement was eventually added to Quest for Community's dust jacket. According to observers, participants in the WCC's second meeting at Evanston, Illinois, were likewise enamored of Nisbet's work [99].

The National Review offered to heal Nisbet's total community through fusion of maximized personal economic freedoms, a rejuvenated moral establishment, and a global military security establishment. Their efforts often ironically replicated the individualist therapeutic tactics of resistance to conformity preached by so many leftist critics. The end result has been the emergence of "postmodern conservativism" [83] that repudiated Burke's belief in slow organic change.

In contrast, traditionalist conservatives turned with Nisbet and the Realists to more communitarian solutions. Weaver, for one, defended private property as a "metaphysical right" but derided "finance capitalism" (i.e., "the aggregation of vast properties under anonymous ownership") as the wellspring of the totalitarian state. Weaver's moral solution was in keeping with Roman Catholic-based decentrism as well as his own Southern Agrarianism: return to "the distributive ownership of small properties," including family farms and businesses, and thereby restore "responsibility" as the hallmark of American economic citizenship ([95], pp. 132-34). Kirk's fondness for Burke's "little platoons" of local community likewise resembled ecumenical writers' "polylithic society" and Hayden's attraction to a "democracy of equal participation" ([93], pp. 412-13). Reading the liberal-conservative binary backwards narrows historians' vision to the clear and expressed differences between Kirk and Niebuhr and makes them miss the many points of contact between their respective communities of discourse. True conservativism, Rossiter summarized of Weaver and Kirk, would be found "between socialism and laisse-faire" ([82], pp. 40-42) — much like the Rooseveltan project had intended.

Accordingly, Nisbet's "new laissez faire" subverted popular usages of the term by tying it to New Deal modernization theory. Nisbet applauded Tennessee Valley Authority director David Lilienthal for proving that "central planning is not inconsistent with local and associative autonomies" ([97], pp. 242-43). Nisbet committed (to libertarians) the inconvenient sin of praising Old Leftists like Mumford, 
Sidney Hook, and even Dewey for their support for "associative pluralism" ([97], pp. 207, 264). In subsequent decades, he became increasingly critical of the libertarian drift of the new conservativism. "Conservatives who aimlessly oppose planning, whether national or local, are their own worst enemies", Nisbet warned in the 1970 preface to his book ([97], p. xxxi). Nisbet's conservativism, in other words, still assumed a large role for the state to reinvigorate, provide for, and protect grassroots forms of democracy.

Viereck likewise joined Nisbet and Christian Realists in locating Burkean conservativism within New Deal liberalism. Niebuhr had boasted that, under FDR's leadership, “America has developed a pragmatic approach to political and economic questions which would do credit to Edmund Burke" [100]. Viereck observed that Burke's conception of tradition was historicist and, thus, open to gradual, pragmatic innovation. While no spokesperson for a "welfare superstate", Burke would not have opposed "humane social reforms" even if they appeared "socialistic" ([86], pp. 37-42). As Viereck maintained, "the Burkean conservative today cherishes New Deal reforms in economics and Lockean parliamentary liberalism in politics as traditions here to stay" ([86], p. 142). Similarly, Metternich's “conservative socialism" allowed Viereck to co-opt Roosevelt and Democratic Presidential candidate Adlai Stevenson as modern-day "Tory socialists" ([86], p. 127). Stevenson came to Viereck's aid on this point when he argued during his 1952 campaign,

The strange alchemy of time has somehow converted the Democrats into the truly conservative party of this country - the party dedicated to conserving all that is best, and building solidly and safely on these foundations. The Republicans, by contrast, are behaving like the radical party - the party of the reckless and the embittered, bent on dismantling institutions which have been built solidly into our social fabric...Our social-security system and our Democratic party's sponsorship of the social reforms and advances of the past two decades [are] conservativism at its best ([86], p. 155).

For Viereck, the true conservative was the realistic democratic Progressive: fighting for the "organic unity" of urban-industrial society against the "atomistic disunity of unregulated capitalism" and, thus, always risking the "totalitarian threat" to responsible freedoms ([86], p. 134).

Traditionalist conservative writings such as Viereck's and claims such as Stevenson's clearly transgressed the liberal-conservative binary formed during the Cold War. The temptation at this point is to conclude simply that postwar conservativism was diverse-which would leave the binary intact. Instead, why not concede that those writers and claims call the historiographical project of pitting "conservatives" versus "liberals" into question? Not only did traditionalist thinkers find much to like in the trans-Atlantic Progressive customs as they became instituted in the New Deal. They also found allies among professing liberals who came to see that very New Deal tradition as a better expression of conservativism than what normally went by that name. "American conservativism is not conservative at all in the traditional sense", Niebuhr observed in 1953. "Our problem", he surmised, "is how to generate the wisdom of true conservativism without losing the humane virtues which the liberal movement developed" [101]. Niebuhr's private longing for a genuinely conservative American political party does not mean he should be renamed a conservative. Instead, the Cold War meeting of Niebuhr, the early WCC, and the traditionalists invite historians to qualify, recast, and perhaps abandon some of their most cherished abstractions. 


\section{Conclusions: The Longer 1960s}

The significance of Tom Hayden's reading list can now better be appreciated. Hayden's New Left styled themselves "radical liberals" travailing against a Cold War liberal establishment that, to them, resembled Buckley's "totalitarian bureaucracy" more than it did anything worthy of the word liberal [102]. New Left historians like James Weinstein and Gabriel Kolko traced liberalism's problems back to the Progressives, who it was argued practiced "corporate liberalism" or "political capitalism" at the expense of real democratic socialism [103]. Ironically, New Left historiography underscored the impossibility of portraying trans-Atlantic Progressives in any kind of monolithic way, since radical liberal efforts to decenter Cold War liberal "bigness" often resembled, if not drew directly upon, the communitarian strands running through Jane Addams, John Dewey, and others [14-16]. The New Left, like their Progressive forbearers, sought a "system of coalition politics...invigorated by participatory democracy" ([102], p. 61).

As has been shown in this essay, the New Left concerns expressed in the PHS were also anticipated by democratic Progressivism's other debtors, including the old ecumenical Protestant left and the early traditionalist New Right. Recognizing the conservativism within the New Left does not entail a reshuffling of ready-made typologies of right and left. Nor does it suggest minimizing the liberationist turn taken by many liberals including the WCC leadership. Rather the point is to admit that those categorization efforts have reduced the complexity as well as creativity of public intellectual communities and their causes. If a nation's history is often best understood from the margins - from its "lost opportunities" or "paths not taken"- then trying to squeeze everyone and everything into a liberal-conservative binary diminishes America's past, present, and future selves.

The New Left's own conservative socialism—admittedly, a marginal discourse — was self-consciously highlighted by one of the movement's cherished Old Left mentors, Paul Goodman. Goodman's willingness to own the "conservative" label was unusual but not unique in a transgressive age when even Buckley the New Right standard bearer could claim his ideological opponent Norman Mailer as a close confidant [104]. Goodman's watershed critique of 1950s conformity, Growing up Absurd (1956), had encouraged young people to drop out of the rat race and pioneer more participatory democratic or "decentrist" modes of living [105,106]. Goodman became a self-proclaimed "conservative anarchist" or "conservationist" fighting against the excessive wastes of "organized society" [107]. He could see that it was not always wrong for the left to be right. "In our runaway, one-sided way of life", he foreknew, "the proposal to conserve human resources and develop human capacities has become a radical innovation" ([105], p. 232). Like Christian Realists and traditionalists before him, Goodman called for a more literal rendering of the word "conservative" in opposition to its increasingly normalized libertarian usage.

In his 1969 statement of principles, New Reformation, Goodman renounced the New Left's turn to revolutionary violence. He promptly invoked Burke on the need to "conserve the community bonds" at all costs ([107], p. 192). "The description of a revolutionary period", Goodman countered, "consists of many accounts of how localities, factories, tradesmen, schools, and communes go about managing their own affairs, defending themselves against the central System, and making whatever federal arrangements are necessary to weave the fabric of society" ([107], pp. 206-07). In other words, 
Goodman found in Burke's "little platoons" rather than in Che Guevera's guerilla warfare a better basis for New Left counterculturalism.

Crucial to advancing the "long 1960s" project - the general appreciation for the lasting and irreversible impact of that decade upon Americans - is documenting the proliferation since that time of communitarian ideals and activism such as Goodman's. Historians have already chronicled the mainstreaming of so-called "front porch politics" as one consequence of 1960s radicalism [108-110]. The participatory and deliberative nature of the new populism has been self-evident, as has the role of various religious traditions in fueling it. In several cases, post-sixties grassroots activism has tended to reinforce rather than subvert the liberal-conservative binary stemming from the Cold War culture wars. On the right, tax revolters and pro-life advocates have effectively coopted participatory democratic procedures [111,112]. Evangelical left groups, in turn, have been deploying micro-social pacifist energies against what they see as the religious right's sell-out to a military-capitalist state and society $[113,114]$.

Yet younger readers on the right and left are finding much to commend in the works of Christopher Lasch and Wendell Berry [115-117]. Though hardly alone among communitarian thinkers from the past half-century - one thinks of Jurgen Habermas and Robert Putnam - Lasch and Berry have offered the most explicit reworking of radical liberal ideas about local over mass community control. The former started in academia as a New Left historian publishing against the tyranny of professional-managerial elites. The latter began his illustrious countercultural career as a New Left agrarian protesting the Vietnam War and racial discrimination. Both have been faithful defenders of the promise of participatory democracy by other names.

The cross-over appeal of such critics is nothing new, however, as this essay has tried to show. It is a part of a long history of transgressions of the Cold War culture wars. Perhaps, then, there is a more meaningful divide in contemporary America than the liberal-conservative one. This is not to conclude that the binary has no value for recounting American fracture over issues of god, family, and country. Yet Trans-Atlantic Progressive writers, Christian Realists, traditionalist conservatives, the New Left, and unaffiliated authors like Lasch and Berry all point to a deeper distinction between those who believe that only the "small is beautiful" and those who find American politico-military and business institutions "too big to fail". To admit that would be to acknowledge the coincidence of Old Left, New Left, and New Right critiques of twentieth-century American bigness - such as in Jonah Goldberg's 2007 book, Liberal Fascism, when he drew upon Kolko's and Weinstein's analyses when blaming the triumph of techno-corporate capitalism on strong-state liberals like Obama [118]. It would also mean looking beyond (or behind) libertarian and leftist demands for personal liberation to the need for more substantial forms of democratic solidarity and cooperation. And, most importantly for this journal, it would be to recognize how long and hard American and world ecumenical Christians have been fighting to conserve the humane scale of life - no matter how strange their bedfellows have been.

\section{Conflicts of Interest}

The author declares no conflict of interest. 


\section{References}

1. Richard Flacks, and Nelson Lichtenstein. The Port Huron Statement: Sources and Legacies of the New Left's Founding Manifesto. Philadelphia: University of Pennsylvania Press, 2015.

2. James Miller. "Democracy is in the Streets": From Port Huron to the Siege o $f$ Chicago. New York: Harvard University Press, 1987.

3. Kevin Mattson. Intellectuals in Action: The Origins of the New Left and Radical Liberalism, 1945-1970. University Park: Penn State University Press, 2002.

4. Heather A. Warren. Theologians of a New World Order: Reinhold Niebuhr and the Christian Realists, 1920-1948. New York: Oxford University Press, 1996.

5. Mark Thomas Edwards. The Right of the Protestant Left: God's Totalitarian ism. New York: Palgrave Macmillan, 2012.

6. Eric Patterson. The Christian Realists: Reassessing th e Contributions of Niebuhr and His Contemporaries. Lanham: University Press of America, 2003.

7. George H. Nash. The Conservative Intellectual Movement in America since 1945 . New York: BasicBooks, 1976.

8. Bethany Moreton. To Serve God and Wal-Mart: The Maki ng of Christian Free Enterprise. Cambridge: Harvard University Press, 2009.

9. Darren Dochuk. From Bible Belt to Sun Belt : Plain-Folk Religion, Grassroots Politics, and the Rise of Evangelical Conservativism. New York: Norton, 2010.

10. Seth Dowland. Family Values: Gender, Authority, and the Rise of the Christian Right Philadelphia: University of Pennsylvania Press, 2016, forthcoming.

11. Patrick Allitt. Catholic Intellectuals and Cons ervative Politics in America, 1950-1985 Ithaca: Cornell University Press, 1993.

12. Simon Hall. "Protest Movements in the 1970s: The Long 1960s." Journal of Contemporary History 43 (2008): 655-72.

13. William James, and George Cotkin. William James: Public Philosopher . Baltimore: Johns Hopkins University Press, 1990, pp. 174-75.

14. Robert B. Westbrook. John Dewey and American Democracy. Ithaca: Cornell University Press, 1991.

15. Kevin Matteson. Creating a Democratic Republic: Th e Struggle for Urban Participatory Democracy during the Progressive Era. University Park: Penn State University Press, 1997.

16. Laura M. Westhoff. A Fatal Drifting Apart: Democratic Social Knowledge and Chicago Reform. Columbus: Ohio State University Press, 2007.

17. David Ekbladh. The Great American Mission: Modern ization and the Construction of an American World Order. Princeton: Princeton University Press, 2010.

18. Drew Maciag. Edmund Burke in America. Ithaca: Cornell University Press, 2013.

19. Andrew Hartman. A War for the Soul of America: A His tory of the Culture Wars. Chicago: University of Chicago Press, 2015.

20. David A. Hollinger. After Cloven Tongues of Fire: Protestant Liberalism in Modern American History. Princeton: Princeton University Press: 2013. 
21. Kevin Schultz. Tri-Faith America: How Catholics and Jews Held Postwar America to Its Protestant Promise. New York: Oxford University Press, 2011.

22. Healan K. Gaston. "The Genesis of America's Judeo-Christian Moment: Secularism, Totalitarianism, and the Redefinition of Democracy." Ph.D. Dissertation, University of California, Berkeley, CA, USA, 2008.

23. Gene Zubovich. "The Global Gospel: Protestant Internationalism and American Liberalism, 1940-1960.” Ph.D. Dissertation, University of California, Berkeley, CA, USA, 2014.

24. Matthew Hedstrom. The Rise of Liberal Religion: Book Culture and American Spirituality in the Twentieth Century. New York: Oxford University Press, 2012.

25. Elesha Coffman. The Christian Century and the Rise of the Protestant Mainline . New York: Oxford University Press, 2013.

26. Jill K. Gill. Embattled Ecumenism: The National Council of Churches, the Vietnam War, and the Trials of the Protestant Left. Dekalb: Northern Illinois University Press, 2011.

27. Andrew Preston. Sword of the Spirit: Shield of Faith: Religion in American War and Diplomacy. New York: Alfred A. Knopf, 2012.

28. Michael Thompson. For God and Globe: Christian Inter nationalism in the United States between the Great War and the Cold War. Ithaca: Cornell University Press, 2016, forthcoming.

29. Cara Burnidge. A Peaceful Conquest: Woodrow Wilson, the League of Nations, and the Great War of the Protestant Establishment. Chicago: University of Chicago Press, 2016, forthcoming.

30. Timothy Gloege. Guaranteed Pure: The Mood y Bible Institute, Business, and the Making of Modern Evangelicalism. Chapel Hill: University of North Carolina Press, 2015.

31. Donald B. Meyer. The Protestant Search for Political Realism, 1919-1941. Berkeley: University of California Press, 1960.

32. Eugene McCarraher. Christian Critics: Religion and the Impasse in Modern Am erican Social Thought. Ithaca: Cornell University Press, 2000.

33. Robin Lovin. Christian Realism and the New Realities. New York: Cambridge University Press, 2008.

34. Gary Dorrien. Social Ethics in th e Making: Interpr eting an American Traditio $n$. Somerset: Wiley Blackwell, 2010.

35. George Hammar. Christian Realism in Contemporary Amer ican Theology: A Study of Reinhold Niebuhr, W. M. Horton, and H. P. Van Dusen. Uppsala: Appelbergs Boktryckeriaktiebolag, 1940.

36. John Coleman Bennett. “After Liberalism —What?” Christian Century 50 (1933): 1403-06.

37. Walter Marshal Horton. Realistic Theology. New York: Harper and Brothers, 1934, p. ix.

38. Samuel McCrea Cavert. "The Younger Theologians." Religion in Life 5 (1936): 520-31.

39. John Coleman Bennett. Christian Realism. New York: Charles Scribner's Sons, 1941.

40. Henry Pitney Van Dusen to Walter Marshall Horton, 10 August 1933. John Coleman Bennett Papers, Burke Library Archives at Union Theological Seminary in the City of New York.

41. Daniel T. Rodgers. Atlantic Crossings: Social Politics in a Progressive Age. Cambridge: Belknap, 1998.

42. Marc Stears. Progressives, Pluralists, and the Problems of the State: Ideologies of Reform in the United States and Britain, 1896-1926. New York: Oxford University Press, 2002.

43. Eldon J. Eisenach. The Lost Promise of Progressivism. Lawrence: University Press of Kansas, 1994. 
44. Francis Pickens Miller to Reinhold Niebuhr, 27 January 1933. World Student Christian Federation Papers, Film Ms. 313, Special Collections, Yale Divinity School Library, Box 8.

45. Keith Clements. Faith on the Frontier: A Life of J. H. Oldham. Geneva: WCC, 1999, pp. 277-79, 334-35.

46. Francis Pickens Miller. "The Christian Community and the Nation-State." (for Visser 't Hooft), 3 June 1933. World's Student Christian Federation Papers, Yale Divinity School Library, Box 6.

47. Francis Pickens Miller. "The New Religion of Nationalism." In The Christian Message for the World Today. Edited by Stanley E. Jones. London: George Allen and Unwin, 1934, pp. 52-73.

48. Dianne Kirby. "Harry S. Truman's International Religious Anti-Communist Front, the Archbishop of Canterbury and the 1948 Inaugural Assembly of the World Council of Churches." Contemporary British History 15 (2001): 35-70.

49. Dianne Kirby. "Harry S. Truman's Religious Legacy: The Holy Alliance, Containment and the Cold War." In Religion and the Cold War . Edited by Dianne Kirby. New York: Palgrave Macmillan, 2003, pp. 77-102.

50. William Inboden. Religion and American Foreign Policy, 1945-1960: The Soul of Containment . New York: Cambridge University Press, 2008.

51. Correspondence between W.A. Visser 't Hooft and Samuel McCrea Cavert, 15 May 1948. World Council of Churches-General Correspondence, Yale Divinity School Library, Microfiche Number 261.

52. Mark Hulsether. Building a Protestant Left: Chri stianity and Crisis Magazine, 1941-1993 . Knoxville: University of Tennessee Press, 1999.

53. Reinhold Niebuhr. "The Victory of British Labor." Christianity and Society 10 (1945): 7-9.

54. Reinhold Niebuhr. "American Liberals and British Labor.” Nation 162 (1946): 682-84.

55. J.H. Oldham. “A Responsible Society.” In Man's Disorder and God's Design: The Amsterdam Assembly Series. Edited by Henry Pitney Van Dusen. New York: Harper and Brothers, 1948, vol. III, p. 146.

56. Donald K. Gorrell. The Age of Social Responsibility: The Soci al Gospel in the Progressive Era, 1900-1920. Macon: Mercer University Press, 1988.

57. No specified author. "Report of Section III: The Church and the Disorder of Society." In Man's Disorder and God's Design: The A msterdam Assembly Series. Edited by Henry Pitney Van Dusen. New York: Harper and Brothers, 1948, vol. III, p. 192.

58. Max Horkheimer, and Theodor W. Adorno. The Dialectic of Enlightenment. New York: Social Studies Association, 1944.

59. Daniel Bell. The End of Ideology: On the Exhausti on of Political Ideas in the Fifties . Glencoe: Free Press, 1960, pp. 21-22.

60. Reinhold Niebuhr. "God's Design and the Present Disorder of Civilisation." In Man's Disorder and God's Design: The Am sterdam Assembly Series. Edited by Henry Pitney Van Dusen. New York: Harper and Brothers, 1948, vol. III, p. 18.

61. Howard N. Tuttle. The Crowd is Untruth: The Existential Critique of Mass Society in the Thought of Kierkegaard, Nietzsche, Heidegger, and Ortega y Gassett. New York: Peter Lang, 1996.

62. James Fisher. The Catholic Counterculture in America, 1933-1962 . Chapel Hill: University of North Carolina Press, 1989. 
63. Francis Pickens Miller. "Discussion Questions: Political Implications of a Responsible Society." 13 January 1951. World Council of Churches Papers, Yale Divinity School Library, Box 33, Folder 226.

64. Francis Pickens Miller. "The Meaning of the Responsible Society for Political Life in America." Report of an American Group, n. d. World Council of Churches Papers, Yale Divinity School Library, Box 33, Folder 228.

65. Francis Pickens Miller. "The Responsible Society.” Study Department, WCC, Geneva, n. d., pp. 5-7. H. Alexander Smith Papers, Mudd Library, Princeton University, Box 280, Folder 9.

66. John Coleman Bennett. "Christian Ethics in Economic Life." In Christian Values and the Economic Life. Edited by John Coleman Bennett. New York: Harper and Brothers, 1954, pp. 246-53.

67. John Coleman Bennett. "A Theological Conception of Goals for Economic Life." In Goals of Economic Life. Edited by Dudley A. Ward. New York: Harper and Brothers, 1953, p. 424.

68. Kevin Mattson. When America Was Great: The Fighting Faith of Liberalism in Postwar America. New York: Routledge, 2004.

69. Marquis W. Childs, and Douglass Cater. Ethics in a Business Society . New York: Harper and Brothers, 1954, pp. 110-11.

70. Kenneth E. Boulding. The Organizational Revolution: A Study in the Ethics of Economic Organization. New York: Harper and Brothers, 1953, pp. 81-82.

71. Reinhold Niebuhr. "Coercion, Self-Interest, and Love." In The Organizational Revolution: A Study in the Ethics of Economic Organization . Edited by Kenneth E. Boulding. New York: Harper and Brothers, 1953, pp. 228-44.

72. John Coleman Bennett. Christians and the State. New York: Charles Scribner's Sons, 1958.

73. J.H. Oldham. Work in Modern Society. London: SCM, 1950, p. 12.

74. Howard R. Bowen. Social Responsibilities of the Businessman. New York: Harper and Brothers, 1953, pp. 20-21.

75. Ernest F. Johnson. "Commentary on the Ethical Implications of the Study." In Social Responsibilities of the Businessman . Edited by Howard R. Bowen. New York: Harper and Brothers, 1953, pp. 257-58.

76. William F. Buckley, Jr. "The Party and the Deep Blue Sea.” Commonweal 55 (1952): 392-93.

77. Lisa McGirr. Suburban Warriors: The Origins of the New American Right . Princeton: Princeton University Press, 2001.

78. Kevin Kruse. White Flight: Atlanta and the Ma king of Modern Conservativism . Princeton: Princeton University Press, 2007.

79. Matthew Lassiter. The Silent Majority: Suburban Politics in the Sunbelt South . Princeton: Princeton University Press, 2007.

80. Kim Phillips-Fein. Invisible Hands: The Businessm an's Crusade against the New Deal. New York: Norton, 2010.

81. Russell Kirk. "A Dispassionate Assessment of Libertarians." In Freedom and Virtue: The Conservative/Libertarian Debate. Edited by George W. Carey. Wilmington: ISI, 2004, pp. 172-86.

82. Clinton Rossiter. Conservativism in America. New York: Alfred A. Knopf, 1956, p. 82. 
83. Kevin Mattson. Rebels All! A Short History of the Conservative Mind in Postwar America. New Brunswick: Rutgers University Press, 2008.

84. Corey Robin. The Reactionary Mind: Conservativism from Edmund Burke to Sarah Palin New York: Oxford University Press, 2011.

85. Peter Viereck. "But—I"m a Conservative!” Atlantic Monthly 165 (1940): 537-43.

86. Peter Viereck. Conservativism Revisited. New York: Free Press, 1962, pp. 34-48.

87. Tom Reiss. "The First Conservative: How Peter Viereck Inspired—and Lost—a Movement." The New Yorker, 24 October 2005. Available online: http:/www.newyorker.com/archive/2005/ 10/24/051024fa_fact1?printable=true (accessed on 10 October 2008).

88. Will Herberg. “Government by Rabble-Rousing.” New Leader 37 (1954): 15-16.

89. Will Herberg. "Reinhold Niebuhr: Burkean Conservative." National Review11 (1961): 379-94.

90. Paul Elie. “A Man for All Reasons.” Atlantic Monthly 300 (2007): 82-92.

91. John Coleman Bennett. "The Christian Response to Social Revolution." Ecumenical Review 9 (1956): 1-15.

92. Jennifer Burns. "Liberalism and the Conservative Imagination." In Liberalism for a New Century. Edited by Neil Jumonville and Kevin Mattson. Berkeley: University of North Carolina Press, 2007, pp. 58-72.

93. Russell Kirk. The Conservative Mind: From Burke to Eliot, 6th ed. South Bend: Gateway, 1978, pp. 390-92.

94. Francis Pickens Miller. "Be Not Conformed." unspecified address, n. d. (circa 1950s). Francis Pickens Miller Papers, Special Collections, Alderman Library, University of Virginia, Box 12.

95. Richard M. Weaver. Ideas Have Consequences. Chicago: University of Chicago Press, 1948, p. vi.

96. John A. Andrew III. The Other Side of the Sixties: Young Americans for Freedom and the Rise of Conservative Politics. New Brunswick: Rutgers University Press, 1997, p. 86.

97. Robert Nisbet. The Quest for Community: A Study in the Ethics of Order and Freedom San Francisco: ISI, 1990, pp. 42-43.

98. Reinhold Niebuhr to Robert Nisbet, 11 January 1954. Robert Nisbet Papers, Manuscript Division, Library of Congress, Box 2.

99. Edward Duff. The Social Thought of the World Council of Churches . New York: Association, 1956, pp. 126-27.

100. Reinhold Niebuhr. The Irony of American History . New York: Charles Scribner's Sons, 1952, p. 89.

101. Reinhold Niebuhr. Christian Realism and Political Problems . New York: Charles Scribner's Sons, 1953, pp. 55, 67, 72 .

102. Arnold S. Kaufman. The Radical Liberal: The New Politics. New York: Simon and Schuster, 1970, pp. xii, 13.

103. Rich Yeselson. "What the New Left Gave Us." Democracy, Winter 2015. Available online: http://www.democracyjournal.org/35/what-new-left-history-gave-us.php?page=all (accessed on 7 January 2015).

104. Kevin Schultz. Buckley and Mailer: The Difficult Friendship that Shaped the 1960s. New York: Norton, 2015.

105. Paul Goodman. Growing Up Absurd. New York: Vintage, 1960, pp. xiii-xiv. 
106. Paul Goodman. People or Personnel: Decentra lization and the Mixed System . New York: Random House, 1963, p. 4.

107. Paul Goodman. New Reformation: Notes of a Neolithic Conservative. New York: Vintage, 1969, pp. 202-06.

108. Michael Stewart Foley. Front. Porch Politics: The Forgotten Heyday of American Activism in the 1970s and 1980s. New York: Hill and Wang, 2013.

109. Heather Ann Thompson. Speaking Out: Activism and Protest in the 1960s and 1970s. New York: Pearson, 2009.

110. Katherine A. Scott. Reining in the State: Civil. Socie ty and Congress in the Vietnam and Watergate Era. Lawrence: University Press of Kansas, 2013.

111. Simon Hall. American Patriotism, American Protes t: Social Movemen ts since the 1960s. Philadelphia: University of Pennsylvania Press, 2010.

112. John A. Shields. The Democratic Virtues of the Religious Right. Princeton: Princeton University Press, 2009.

113. David Swartz. Moral Minority: The Evangelical Le ft in an Age of Conservativism Philadelphia: University of Pennsylvania Press, 2012.

114. Brantley Gasaway. Progressive Evangelicals and the Pursuit of Justice. Chapel Hill: University of North Carolina Press, 2014.

115. Seth J. Bartee. "Christopher Lasch, Conservative?" The University Bookman, Spring 2012, Available online: http://www.kirkcenter.org/index.php/bookman/article/christopher-laschconservative/ (accessed on 7 January 2015).

116. Eric Miller. Hope in a Scattering T ime: A Life of Christopher Lasch . Grand Rapids: Wm. B. Eerdmans, 2010.

117. Rod Dreher. "Wendell Berry: A Real Conservative." The American Conservative, 28 April 2012. Available online: http://www.theamericanconservative.com/dreher/wendell-berry-a-realconservative/ (accessed on 7 January 2015).

118. Jonah Goldberg. Liberal Fascism. New York: Doubleday, 2007, pp. 284-316.

(C) 2015 by the author; licensee MDPI, Basel, Switzerland. This article is an open access article distributed under the terms and conditions of the Creative Commons Attribution license (http://creativecommons.org/licenses/by/4.0/). 